\title{
$\beta 2$ adrenergic receptor polymorphisms and nocturnal blood pressure dipping status in the Wisconsin Sleep Cohort Study
}

\author{
Orly Vardeny, Pharm.D., M.S., Paul E. Peppard, Ph.D., Laurel A. Finn, M.S., Juliette H. \\ Faraco, Ph.D., Emmanuel Mignot, M.D., Ph.D., and Khin Mae Hla, M.D., M.H.S. \\ University of Wisconsin School of Pharmacy (O.V); Departments of Population Health Sciences \\ (P.E.P, L.A.F) and Medicine (K.M.H.), University of Wisconsin School of Medicine \& Public \\ Health; and Stanford University School of Medicine Center for Sleep Sciences and Department of \\ Psychiatry (J.H.F, E.M), Palo Alto, CA.
}

\begin{abstract}
Non-dipping nocturnal blood pressure (BP) is associated with target organ damage and cardiovascular disease. We hypothesized that $\beta 1$ - and $\beta 2$-AR-associated SNPs would associate with non-dipping BP patterns. Participants ( $N=497$, age range 30-74 years, $40 \%$ female) of the Wisconsin Sleep Cohort Study with at least one ambulatory BP monitoring test were included. Non-dipping was defined as less than a $10 \%$ dip in sleep BP compared to wake BP. Dipping ratios were calculated as sleep/wake BP. Single nucleotide polymorphisms in the $\beta 1$-AR (rs7076938, tagging for Gly389Arg) and $\beta 2-\mathrm{AR}$ (rs17778257 and rs2400707, tagging for Arg16Gly and Gln27Glu) were selected. $\beta 2$-AR SNP rs2400707 A-positive subjects (tagging for Glu27) had higher systolic and diastolic dipping ratios in a dose-response fashion. Systolic dipping ratios were: $\mathrm{GG}=0.846 ; \mathrm{AG}=0.854 ; \mathrm{AA}=0.861$ ( $\mathrm{p}$-trend=0.015). Diastolic dip ratios were: $\mathrm{GG}=0.807$; $\mathrm{AG}=0.815 ; \mathrm{AA}=0.824$ (p-trend=0.026). The $\beta 2$-AR rs17778257/rs2400707 A/A haplotype was associated with dipping ratios and systolic non-dipping status (non-dipping OR 2.0 [1.0, 3.8] for A/A versus A/G). Results were similar when models included participants on antihypertensive medications. Higher dipping ratios indicating a lack of nocturnal BP dipping are associated with $\beta 2$-AR polymorphisms. Nocturnal dipping patterns may be modulated by $\beta 2$-AR polymorphisms.
\end{abstract}

\section{Keywords}

single nucleotide polymorphisms; sympathetic nervous system; ambulatory blood pressure

\section{INTRODUCTION}

Ambulatory blood pressure monitoring (ABPM) provides useful information that is not captured from conventional office-based blood pressure (BP) measurement, such as mean BP over 24 hours and night-day patterns. In most healthy individuals, nocturnal BP dips by 10-20\% compared to daytime values ${ }^{1}$. Persons that lack a normal decline in BP are referred

\footnotetext{
(C) 2011 American Society of Hypertension. Published by Elsevier Inc. All rights reserved.

Address Correspondence to: Orly Vardeny, Pharm.D., M.S., University of Wisconsin School of Pharmacy, 777 Highland Avenue, Madison, WI 53705-2222, Phone: 608.265.0591, Fax: 608.265.5421, ovardeny @ pharmacy.wisc.edu.

Publisher's Disclaimer: This is a PDF file of an unedited manuscript that has been accepted for publication. As a service to our customers we are providing this early version of the manuscript. The manuscript will undergo copyediting, typesetting, and review of the resulting proof before it is published in its final citable form. Please note that during the production process errors may be discovered which could affect the content, and all legal disclaimers that apply to the journal pertain.

DISCLOSURES: none
} 
to as "nondippers", while individuals with a normal diurnal BP variation are termed "dippers" 2 . Studies of both hypertensive and normotensive individuals found ambulatory $\mathrm{BP}$, and specifically nighttime BP, to better predict cardiovascular morbidity compared to clinic and daytime $\mathrm{BP}^{3-5}$. Non-dipping has been associated with target organ damage, including development and progression of renal disease, cerebrovascular disease, and cardiovascular morbidity and mortality. ${ }^{5-8}$

The mechanisms accounting for individual differences in dipping patterns are incompletely understood. Autonomic imbalance is a feature of many cardiovascular risk factors such as diabetes and chronic heart failure, and is likely an important mechanism underlying impaired diurnal BP variation. The sympathetic nervous system (SNS) plays a major role in $\mathrm{BP}$ regulation and is considered to be a potential factor in the magnitude of nocturnal BP variation. ${ }^{9}$ Norepinephrine and epinephrine levels show a diurnal variation, with reduced levels during nighttime sleep. ${ }^{10}$ One study showed attenuated urinary norepinephrine and epinephrine reduction in non-dippers compared to dippers, lending weight to the hypothesis that adrenergic stimulation is a factor in night time BP regulation. Given the importance of the SNS in BP regulation, including diurnal variation, genetic variations underlying adrenergic receptor structure and function may be associated nocturnal BP dipping.

Beta-adrenergic receptor ( $\beta$-AR) single nucleotide polymorphisms (SNPs) have been associated with hypertension and responses to antihypertensive medications ${ }^{11,12}$ —as well as survival following acute coronary syndrome, ${ }^{13}$ and metabolic outcomes in cardiac patients ${ }^{14}$ - but their relation with 24 -hour BP variation has not been explored. The beta-1 and beta- 2 adrenergic receptors ( $\beta 1-\mathrm{AR}$ and $\beta 2$-AR, respectively) are G-protein-coupled receptors that specifically bind and are activated by endogenous catecholamines including epinephrine. Single nucleotide polymorphisms are known to map within the $2.89 \mathrm{~kb} A D R B 1$ and $2 \mathrm{~kb} A D R B 2$ genes, including those that change amino acid encoding and several with documented functional relevance. ${ }^{15,16,17}$ In this study, we hypothesized that $\beta 1$ - and $\beta 2$-ARassociated SNPs would be related to non-dipping BP patterns. We chose to examine the beta-adrenergic system as these polymorphisms are frequent in the general population, data are available regarding their functional significance on post-receptor activities, and previous research supports their association with blood pressure and response to antihypertensive medications. The alpha adrenergic receptor mediates vasoconstriction and catecholamine release, but data are limited as to its role in blood pressure regulation. To explore associations of $\beta$-AR genetic variants with non-dipping patterns, we used a population-based large sample of men and women participating in the ongoing Wisconsin Sleep Cohort Study who had both 24-hour ambulatory blood pressure measurements (to assess BP dipping) and have been genotyped on high density genotyping arrays. ${ }^{18}$

\section{METHODS}

The study sample consisted of a subset of 497 individuals enrolled in the Wisconsin Sleep Cohort Study from 1991-2003. The protocols and design for Wisconsin Sleep Cohort Study protocols and informed consent documents were approved by the Health Sciences Institutional Review Board at the University of Wisconsin, and have been previously described. ${ }^{19}$. Briefly, the sample consisted of a probability sample of employees of 4 Wisconsin state agencies, aged 30-60 years, invited to undergo an overnight sleep study protocol at baseline and follow up studies at 4-year intervals. Exclusion criteria for the main study were pregnancy, unstable cardiopulmonary disease, airway cancers, and recent surgery involving the upper airway. For this specific analysis, participants with at least one ABPM measurement and who provided blood for genetic typing were included; for most analyses, individuals taking antihypertensive medications - which may affect diurnal BP patternswere excluded $(n=258)$, leaving 497 subjects and 802 ABPM events for analysis. 


\section{Data collection}

Ambulatory-wake blood pressure measurement-ABPM studies were performed with the Accutracker II (SuntechMedical Instruments/Eutectics Electronics, Raleigh, NC), a 24-hour BP monitoring device that uses a modified auscultatory method. Details of the study protocol and ABPM quality data have been previously published. ${ }^{20} \mathrm{ABPM}$ readings were obtained at random intervals averaging every 15 to 20 minutes during wakefulness and every 30 minutes during sleep. All daily activities could be performed while wearing the monitor except showering or bathing, although vigorous exercise during the protocol was discouraged. Activity, posture, bedtime, and time on awakening from sleep were recorded by participants on diaries. Individual mean sleep and wake BPs were computed by averaging ABPM measurements during sleep and wake defined by participants' recorded sleep and wake times. The wake BP readings were averaged to obtain one measure for an ambulatorywake systolic BP reading and one measure for an ambulatory-wake diastolic BP reading. Similar calculations were made to obtain average readings for sleep systolic and diastolic BP. Non-dipping was defined as less than a $10 \%$ dip in mean sleep BP compared to mean wake BP. Dipping ratios were calculated as mean sleep BP divided by mean wake BP.

Genotyping-Genotyping of members of the Wisconsin Cohort on the Affymetrix 500K arrays set , and 6.0 chips has been previously described. ${ }^{18}$ Genotype calling was performed using the Birdseed-dev algorithm for Affy 6.0 and BRLMM for Affy 500K arrays set chips, and data was stored in our Progeny Lab 7 database. Proxy SNPs were identified by analyzing HAPMAP linkage disequilibrium (LD) data for the CEU population (www.Hapmap.org), and selecting SNPs with the highest $\mathrm{r}^{2}$ values that were present on the Affymetrix chips. It is important to note that although we used Affymetrix data, in this analysis we tested a specific hypothesis related to nondipping and $\beta$-AR variants; it was not our goal to perform a genome wide association study of nondipping due to our limited sample size. In the ADRB1 receptor two frequent SNPs have been extensively studied: rs1801252 encoding Ser49Gly, located in the extracellular N terminus, and rs1801253 encoding Gly389Arg within the proximal C terminal region, crucial for G-protein coupling. ${ }^{21}$ No suitable Affymetrix platform SNP proxies could be identified for rs1801252, however SNP rs7076938 on the Affymetrix 6.0 chip had an $\mathrm{r}^{2}$ value of 0.91 with rs 1801253 Gly389Arg, and was selected as a proxy for analysis (Table 1). In the ADRB2 gene, two common SNPs have undergone extensive functional study: rs1042713 encoding Arg16Gly, and rs1042714 encoding Gln27Glu. Located only 33 base pairs apart, the two SNPs occur in three common diplotypes. Two SNPs were chosen as proxies that were located on both the Affymetrix 500K and 6.0 chip platforms: rs 17778257 had an r2 value of 0.94 with rs1042713, and rs2400707 had an r2 value of 0.96 with rs1042714. Genotypes for 5 markers rs11168066, rs11959615, rs17778257, rs2400707, and rs2116715) in the region were extracted. Haplotypes were examined in Haploview, and phasing was performed in Plink. Phasing results for the two marker haplotype were unambiguous in all cases with a posterior probability of 1 in all samples.

Statistical Analyses-SAS software, version 9.1.3 (SAS Institute, Cary, NC) was used for all statistical analysis. Approximately half (42\%) of the participants in this study underwent more than one ABPM at 4-year intervals, thus specialized techniques were used to account for the intrasubject correlation. Mixed models for continuous outcomes and generalized estimating equation (GEE) techniques for binary outcomes, PROC MIXED (SAS Institute Inc. SAS/STAT Software Release 9.1. Cary, NC: SAS Institute, 2002-2003.) and PROC GENMOD (The GENMOD Procedure. SAS/STAT Software: Changes and Enhancements through Release 6.11. Cary, N.C.: SAS Institute Inc., 1996.) computed robust standard errors for hypothesis testing. Unadjusted models with the genotype group as a categorical predictor variable were first used to identify potential differences between the 
baseline demographics of the groups. Then, multiple mixed regression models were used to asses relationships between each SNP and haplotype and systolic and diastolic dipping ratios and multiple GEE regression models were used to asses relationships between each SNP and haplotype and presence of systolic and diastolic non-dipping. Model covariates, chosen $a$ priori, included age, sex, body mass index (BMI), and self-reported "heritage" (countries of recent ancestral origin). Other covariates such as apnea-hypopnea index (AHI) - a measure of sleep disordered breathing - and cardiovascular disease were not included as they did not improve the models' ability to detect genotype associations. Presence/absence of allelic variants (C/T for rs7076938 [tagging Gly389Arg]; G/A for rs2400707 [tagging Gln27Glu], and A/T for rs17778257 [tagging Arg16Gly]) and haplotypes were examined as the predictor variables in all models. In addition, trend tests for number of each allelic variants and haplotypes $(0,1$ or 2$)$ predicting BP dipping ratios and non-dipping was performed. Pvalues of less than 0.05 for all tests (Chi-square and t-tests) were used to indicate statistical significance.

\section{RESULTS}

\section{Subjects}

Baseline characteristics of all the analyzed subjects, and broken down by genotype groups, are shown in Tables 2 and 3. We included 497 individuals and a total of 802 ABPM tests as follows: 290 participants contributed one test, 135 participants contributed 2 tests (with 4 years between tests), and 72 contributed 3 tests (4 years apart). Of 497 participants not taking antihypertensives, mean age was $51 \pm 8$ (range 30-74 years), and $199(40 \%)$ were female. Mean BMI was $30 \pm 5$ (range 17-52). Participants homozygous for AA of rs2400707 were of similar ages and BMI compared to those homozygous for GG. Likewise for rs17778257 and rs7076938, individuals from the different genotypes were similar in characteristics. Participants grouped into three major haplotypes: T/G (64.6\%, tagging for Arg16Gln27), A/G (34.2\%, tagging for Gly16Gln27), and A/A (65.1\%, tagging for Gly16Glu27), and two participants carried the rare T/A haplotype, tagging for Arg16Glu27.

\section{Dipping, non-dipping, and dipping ratios}

Using JNC VII criteria for hypertension classification, ${ }^{22} 65$ (13\%) were considered to have hypertension based on wake BP readings. Mean wake BP for the group was 126/77 $\mathrm{mmHg}$, and mean sleep BP was 107/62 mmHg. Mean systolic dipping ratio in the study sample was $0.85 \pm 0.06$, and mean diastolic dipping ratio was $0.81 \pm 0.07$. Of $802 \mathrm{ABPM}$ tests, 143 $(18 \%)$ and $87(11 \%)$ exhibited systolic and diastolic dipping ratios $>0.9$, indicative of a nondipping status. Of note, out of 207 individuals that had multiple ABPM tests, 52 had a discordant dipper/non-dipper status between tests. However, in 36 (69\%) out of 52 of the discordant tests a participant who was first classified as a dipper was later found to have a non-dipping status on a subsequent test.

\section{Association of $\beta$-AR SNP with non-dipping status and dipping ratios}

Participants with the $32-\mathrm{AR}$ rs2400707 AA and AG genotypes (tagging for Glu27Glu and Gln27Glu) had $68 \%$ and $19 \%$ higher risks for non-dipping compared to those with the GG genotype (Table 4). Of individuals with a systolic BP non-dipping status, $109(41 \%)$ had at least one A allele of the $\beta 2$-AR rs 2400707 variant. For diastolic non-dipping status, 64 (27\%) had AA or AG genotypes of the $\beta 2-\mathrm{AR}$ rs 2400707 variant. Similarly, individuals with an AA genotype exhibited higher systolic dipping ratios compared to those with AG and GG genotypes ( 0.861 versus 0.854 and 0.846 , p-trend=0.015) (Table 5), and AA positive individuals also had higher diastolic dipping ratios compared to those with AG and GG genotypes ( 0.824 versus 0.815 and 0.807 , p-trend=0.026). In contrast, the $\beta 1$-AR rs 7076938 and $\beta 2$-AR rs 17778257 polymorphisms were not associated with non-dipping status or 
systolic and diastolic dipping ratios. Of note, results were similar when models were repeated including patients on antihypertensive medications.

When examining dipping status and dipping ratios by $\beta 2$-AR haplotypes, the A/A haplotype (tagging for Gly16Glu27) had a two-fold higher risk for systolic non-dipping. The A/G haplotype was associated with a reduced risk for diastolic, but not systolic, non-dipping (ptrend=0.04), and the T/G haplotype not associated with non-dipping status. For dipping ratios, individuals carrying 2 copies of the A/A haplotype had significantly higher systolic ( 0.86 versus 0.855 and 0.847 , p-trend $=0.03$ ) and diastolic ( 0.823 versus 0.816 and 0.807 , ptrend=0.04) dipping ratios compared with those who had one or no copies of the A/A haplotype. There was a trend toward higher systolic and diastolic dipping ratios among participants with the A/A haplotype compared to those with the A/G haplotype (systolic dipping ratio 0.860 versus $0.834, \mathrm{p}=0.07$, diastolic dipping ratio 0.823 versus 0.792 , $\mathrm{p}=0.06$ ). As in single SNP analyses, results did not differ when models included those on antihypertensive medications.

\section{DISCUSSION}

We found that in mostly non-hypertensive individuals, the $\beta 2$-AR rs 2400707 polymorphism was associated with non-dipping status and dipping ratios, such that A allele (tagging for Glu27) positive individuals had higher systolic and diastolic dipping ratios and greater risk for a non-dipping status. Moreover, we noted that the $\beta 2$-AR rs17778257/rs2400707 A/A haplotype (tagging for Gly16Glu27) was also associated with systolic non-dipping and systolic and diastolic dipping ratios. Finally, we did not detect significant associations between the $\beta 1$-AR variant and non-dipping status and dipping ratios. These data suggest that the beta-adrenergic system, and specifically $\beta 2$-AR activities, may influence BP dipping, and as such that genetic polymorphisms affecting $\beta 2$-AR function may be associated with nocturnal BP variations.

The timing of onset of CV events strongly parallels the circadian rhythm of BP. ${ }^{23,24}$ The absence of a normal drop in blood pressure from day to night is predictive of heart failure, myocardial infarction, stroke, as well as sudden cardiac death. ${ }^{25}$ Non-dipping has also been associated with increased left ventricular mass and wall thickness in hypertensive adults. ${ }^{26}$ Mechanisms for blunted nocturnal BP dipping are poorly understood, but are thought to involve the SNS. ${ }^{27}$ It is therefore of interest to examine factors which may modify SNS activity, such as genetic variations of the beta adrenergic receptors.

In our study, participants with the $\beta 2$-AR rs2400707 (proxying Gln27Glu) AG or AA genotype had higher dipping ratios compared to those with the GG genotype, and were more likely to exhibit a non-dipping nocturnal BP pattern. Since the rs 2400707 is in tight LD with the Gln27Glu $\beta 2$-AR variant ( $\mathrm{r} 2=0.96$, with rs2400707A tagging the Glu27 variant), our data is consistent with previous findings suggesting that the $\beta 2$-AR Glu27 genotype is associated with systolic and diastolic blood pressure.$^{28-30}$ Bray et al reported significantly higher blood pressures in participants with ADRB2 genotypes Gly16/Gly16 or Gly16/Arg16, proxied in our analysis by rs 17778257, and higher frequencies of the Glu27 genotype among hypertensive individuals. ${ }^{28}$ However, opposite results have also been suggested; in another study of 522 hypertensive adults, the ADRB2 Gln27/Gln27 genotype was associated with higher systolic BP compared to Gln27/Glu27 genotype. ${ }^{31}$ It is also important to note, however, that several other studies did not find an association with the Arg16Gly and Gln27Glu polymorphisms and hypertension phenotypes. ${ }^{32,33}$ One potential explanation for these disparate findings is the lack of haplotype analyses, an especially relevant consideration as the Arg16Gly and Gln27Glu polymorphisms are tightly linked. 
A number of potential mechanisms could explain how the $32-\mathrm{AR}$ A/A haplotype (proxying for Gly16Glu27) may be associated with non-dipping BP patterns. The Gly16 genotype portends attenuated vasodilatory responses to catecholamines. ${ }^{34}$ This may be a contributing genetic component in the regulation of systemic arterial pressure, such that individuals homozygous for Gly16 may have impaired nocturnal vasodilatory responses, leading to a non-dipping pattern of blood pressure. The functional $\beta 2$-AR polymorphism rs 1042714 (Gln27Glu, or C79G) is in tight LD with our genotyped $\beta 2$-AR rs2400707 variant. Functional studies of this polymorphism suggest that the Glu27 allele is subject to less pronounced agonist-stimulated receptor downregulation compared to the Gln27 allele, ${ }^{35}$ but implications for nocturnal blood pressure responses remain unclear.

We did not detect a significant association of the $\beta 1$-AR rs7076938 polymorphism with dipping ratios and non-dipping status. This variant is also in tight $L D$ with another known $\beta 1$-AR variant with functional effects, $r 1801253$ (Arg389Gly, $r 2=0.91$ ). This variant has been shown to alter post-receptor signaling, with the Arg389 receptor (tagged by rs7076938T) coupling more efficiently with its corresponding G protein (Gs). ${ }^{36}$ Although a few studies found the Arg389 receptor to correlate with blood pressure, ${ }^{37,38}$ other studies failed to find allelic differences between hypertensive and normotensive subjects with either the Ser49Gly (encoded by rs1801252) or the Arg389Gly variants. ${ }^{39,40}$ In our study, it is possible that with reduced catecholamine stimulation of $\beta 1$ receptors at night, these genetic variants may not be as influential on 24-hour blood pressure patterns. We were unable to perform haplotype studies, as rs 1801252 has not been typed on the HapMap, and we were unable to identify an Affymetrix SNP proxy. Moreover, in the context of greater importance of $\beta-2$ adrenergic responses on vasodilation, the $\beta-1$ adrenergic receptor polymorphisms may not play major roles as risk factors for human hypertension, and our study is likely underpowered to detect subtle associations associated with $\beta-1$ polymorphisms.

Several limitations to our study should be noted. First, we did not directly genotype the SNPs encoding the commonly studied $\beta 1$ and $\beta 2$-AR genetic variants as part of the chip used for genetic analyses in the Wisconsin Sleep Cohort Study. Nonetheless, the genetic variants we chose to examine are in tight $\mathrm{LD}$ with the polymorphisms of interest, and we are confident that these variants can be used as proxy polymorphisms with sound results. Second, we cannot link genetic data with catecholamine activity since we did not measure catecholamine concentrations in this study. As such we cannot discount the possibility that catecholamine levels, and not activity at the $\beta$-adrenergic receptor, drive the non-dipping phenomenon. Future studies will need to address the potential interaction of $\beta$-AR genotype with catecholamine levels on night time blood pressure dipping more specifically. Since systolic blood pressure is especially subject to effects of the SNS, we expected stronger genetic associations with systolic non-dipping status, but observed somewhat stronger associations with diastolic non-dipping status. It is possible that mean daytime systolic blood pressures observed in this study were lower than in other studies examining blood pressure due to the younger mean age of our cohort or the exclusion of treated hypertensives in a population with relatively high health insurance coverage. Our study subjects were mostly normotensive and only $13 \%$ were classified as (untreated) hypertensive. Therefore, our results cannot be extrapolated to hypertensive individuals and it is possible that patients with elevated blood pressure may exhibit differing nocturnal blood pressure phenotypes in relation to $\beta$-AR genotypes. We did, however, repeat our analyses including those on antihypertensive agents, and results did not differ significantly. Due to the small percentage of non-dippers in this mostly normotensive cohort, we also cannot exclude the possibility that genetic associations found are due to chance alone. There are few studies examining genetic associations with 24-hour blood pressure variations. Our study provides new information regarding a potential link between SNS activity and nocturnal dipping status 
and dipping ratios, however, due to limited information in this area our results require further verification.

\section{PERSPECTIVES}

Our study may elucidate potential mechanisms of abnormal dipping patterns and their possible link to genetic variation within the $\beta 2$-AR. Future studies should examine whether therapies specifically targeting the SNS could be beneficial in patients with certain genetic profiles and nocturnal non-dipping blood pressure patterns. Moreover, further elucidation of optimal timing of antihypertensive medications in the setting of patients with genetic predisposition to non-dipping blood pressure patterns may be warranted.

\section{CONCLUSION}

In conclusion, we found that the $\beta 2-\mathrm{AR}$ rs $2400707 / \mathrm{rs} 17778257 \mathrm{~A} / \mathrm{A}$ haplotype and rs2400707 polymorphism are associated with nocturnal blood pressure dipping status and dipping ratios among mostly normotensive adults. These results suggest that genetic predisposition involving the sympathetic nervous system may play a role in abnormal blood pressure dipping patterns.

\section{Acknowledgments}

Funding Sources: supported by grants (1KL2RR025012-01, 1UL1RR025011, R01HL62252, R01CA53786, 3P50NS023724) from the National Institutes of Health

\section{REFERENCES}

1. Pickering TG, Shimbo D, Haas D. Ambulatory blood-pressure monitoring. N Engl J Med. 2006 Jun 1; 354(22):2368-2374. [PubMed: 16738273]

2. O'Brien E, Sheridan J, O'Malley K. Dippers and non-dippers. Lancet. 1988 Aug 13.2(8607):397. [PubMed: 2899801]

3. Dolan E, Stanton A, Thijs L, et al. Superiority of ambulatory over clinic blood pressure measurement in predicting mortality: the Dublin outcome study. Hypertension. $2005 \mathrm{Jul}$; 46(1): 156-161. [PubMed: 15939805]

4. Ohkubo T, Imai Y, Tsuji I, et al. Prediction of mortality by ambulatory blood pressure monitoring versus screening blood pressure measurements: a pilot study in Ohasama. J Hypertens. 1997 Apr; 15(4):357-364. [PubMed: 9211170]

5. Ohkubo T, Imai Y, Tsuji I, et al. Relation between nocturnal decline in blood pressure and mortality. The Ohasama Study. Am J Hypertens. 1997 Nov; 10(11):1201-1207. [PubMed: 9397237]

6. Lurbe E, Redon J, Kesani A, et al. Increase in nocturnal blood pressure and progression to microalbuminuria in type 1 diabetes. N Engl J Med. 2002 Sep 12; 347(11):797-805. [PubMed: 12226150]

7. Davidson MB, Hix JK, Vidt DG, Brotman DJ. Association of impaired diurnal blood pressure variation with a subsequent decline in glomerular filtration rate. Arch Intern Med. 2006 Apr 24; 166(8):846-852. [PubMed: 16636209]

8. Kario K, Pickering TG, Matsuo T, Hoshide S, Schwartz JE, Shimada K. Stroke prognosis and abnormal nocturnal blood pressure falls in older hypertensives. Hypertension. 2001 Oct; 38(4):852857. [PubMed: 11641298]

9. Sica DA. What are the influences of salt, potassium, the sympathetic nervous system, and the reninangiotensin system on the circadian variation in blood pressure? Blood Press Monit. 1999; 4 Suppl 2:S9-S16. [PubMed: 10822417]

10. Linsell CR, Lightman SL, Mullen PE, Brown MJ, Causon RC. Circadian rhythms of epinephrine and norepinephrine in man. J Clin Endocrinol Metab. 1985 Jun; 60(6):1210-1215. [PubMed: 3998066] 
11. Filigheddu F, Reid JE, Troffa C, et al. Genetic polymorphisms of the beta-adrenergic system: association with essential hypertension and response to beta-blockade. Pharmacogenomics J. 2004; 4(3):154-160. [PubMed: 15069461]

12. Pacanowski MA, Gong Y, Cooper-Dehoff RM, et al. beta-adrenergic receptor gene polymorphisms and beta-blocker treatment outcomes in hypertension. Clin Pharmacol Ther. 2008 Dec; 84(6):715721. [PubMed: 18615004]

13. Lanfear DE, Jones PG, Marsh S, Cresci S, McLeod HL, Spertus JA. Beta2-adrenergic receptor genotype and survival among patients receiving beta-blocker therapy after an acute coronary syndrome. Jama. 2005 Sep 28; 294(12):1526-1533. [PubMed: 16189366]

14. Vardeny O, Detry MA, Moran JJ, Johnson MR, Sweitzer NK. The beta2 adrenergic receptor Gln27Glu polymorphism affects insulin resistance in patients with heart failure: possible modulation by choice of beta blocker. J Cardiovasc Pharmacol. 2008 Dec; 52(6):500-506. [PubMed: 19034036]

15. Taylor MR, Bristow MR. The emerging pharmacogenomics of the beta-adrenergic receptors. Congest Heart Fail. 2004 Nov-Dec; 10(6):281-288. [PubMed: 15591842]

16. Kobilka BK, Dixon RA, Frielle T, et al. cDNA for the human beta 2-adrenergic receptor: a protein with multiple membrane-spanning domains and encoded by a gene whose chromosomal location is shared with that of the receptor for platelet-derived growth factor. Proc Natl Acad Sci U S A. 1987 Jan; 84(1):46-50. [PubMed: 3025863]

17. Hawkins GA, Tantisira K, Meyers DA, et al. Sequence, haplotype, and association analysis of ADRbeta2 in a multiethnic asthma case-control study. Am J Respir Crit Care Med. 2006 Nov 15; 174(10):1101-1109. [PubMed: 16931635]

18. Hallmayer J, Faraco J, Lin L, et al. Narcolepsy is strongly associated with the T-cell receptor alpha locus. Nat Genet. 2009 Jun; 41(6):708-711. [PubMed: 19412176]

19. Young T, Palta M, Dempsey J, Skatrud J, Weber S, Badr S. The occurrence of sleep-disordered breathing among middle-aged adults. N Engl J Med. 1993 Apr 29; 328(17):1230-1235. [PubMed: 8464434]

20. Hla KM, Young TB, Bidwell T, Palta M, Skatrud JB, Dempsey J. Sleep apnea and hypertension. A population-based study. Ann Intern Med. 1994 Mar 1; 120(5):382-388. [PubMed: 8304655]

21. Dorn GW 2nd. Adrenergic signaling polymorphisms and their impact on cardiovascular disease. Physiol Rev. Jul; 90(3):1013-1062. [PubMed: 20664078]

22. Chobanian AV, Bakris GL, Black HR, et al. The Seventh Report of the Joint National Committee on Prevention, Detection, Evaluation, and Treatment of High Blood Pressure: the JNC 7 report. Jama. 2003 May 21; 289(19):2560-2572. [PubMed: 12748199]

23. Muller JE, Stone PH, Turi ZG, et al. Circadian variation in the frequency of onset of acute myocardial infarction. N Engl J Med. 1985 Nov 21; 313(21):1315-1322. [PubMed: 2865677]

24. Cohen MC, Rohtla KM, Lavery CE, Muller JE, Mittleman MA. Meta-analysis of the morning excess of acute myocardial infarction and sudden cardiac death. Am J Cardiol. 1997 Jun 1; 79(11): 1512-1516. [PubMed: 9185643]

25. Staessen JA, Thijs L, Fagard R, et al. Predicting cardiovascular risk using conventional vs ambulatory blood pressure in older patients with systolic hypertension. Systolic Hypertension in Europe Trial Investigators. Jama. 1999 Aug 11; 282(6):539-546. [PubMed: 10450715]

26. Rizzoni D, Muiesan ML, Montani G, Zulli R, Calebich S, Agabiti-Rosei E. Relationship between initial cardiovascular structural changes and daytime and nighttime blood pressure monitoring. Am J Hypertens. 1992 Mar; 5(3):180-186. [PubMed: 1575945]

27. Sherwood A, Steffen PR, Blumenthal JA, Kuhn C, Hinderliter AL. Nighttime blood pressure dipping: the role of the sympathetic nervous system. Am J Hypertens. 2002 Feb; 15(2 Pt 1):111118. [PubMed: 11863245]

28. Bray MS, Krushkal J, Li L, et al. Positional genomic analysis identifies the beta(2)-adrenergic receptor gene as a susceptibility locus for human hypertension. Circulation. 2000 Jun 27; 101(25): 2877-2882. [PubMed: 10869257]

29. Masuo K, Katsuya T, Fu Y, Rakugi H, Ogihara T, Tuck ML. Beta2- and beta3-adrenergic receptor polymorphisms are related to the onset of weight gain and blood pressure elevation over 5 years. Circulation. 2005 Jun 28; 111(25):3429-3434. [PubMed: 15956122] 
30. Snieder H, Dong Y, Barbeau P, et al. Beta2-adrenergic receptor gene and resting hemodynamics in European and African American youth. Am J Hypertens. 2002 Nov; 15(11):973-979. [PubMed: 12441217]

31. Wallerstedt SM, Eriksson AL, Ohlsson C, Hedner T. Haplotype association analysis of the polymorphisms Arg16Gly and Gln27Glu of the adrenergic beta2 receptor in a Swedish hypertensive population. J Hum Hypertens. 2005 Sep; 19(9):705-708. [PubMed: 15931235]

32. Herrmann SM, Nicaud V, Tiret L, et al. Polymorphisms of the beta2 -adrenoceptor (ADRB2) gene and essential hypertension: the ECTIM and PEGASE studies. J Hypertens. 2002 Feb; 20(2):229235. [PubMed: 11821707]

33. Kato N, Sugiyama T, Morita H, et al. Association analysis of beta(2)-adrenergic receptor polymorphisms with hypertension in Japanese. Hypertension. 2001 Feb; 37(2):286-292. [PubMed: 11230287]

34. Green SA, Turki J, Innis M, Liggett SB. Amino-terminal polymorphisms of the human beta 2adrenergic receptor impart distinct agonist-promoted regulatory properties. Biochemistry. 1994 Aug 16; 33(32):9414-9419. [PubMed: 7915137]

35. Dishy V, Sofowora GG, Xie HG, et al. The effect of common polymorphisms of the beta2adrenergic receptor on agonist-mediated vascular desensitization. N Engl J Med. 2001 Oct 4; 345(14):1030-1035. [PubMed: 11586955]

36. Mason DA, Moore JD, Green SA, Liggett SB. A gain-of-function polymorphism in a G-protein coupling domain of the human beta1-adrenergic receptor. J Biol Chem. 1999 Apr 30; 274(18): 12670-12674. [PubMed: 10212248]

37. Bengtsson K, Melander O, Orho-Melander M, et al. Polymorphism in the beta(1)-adrenergic receptor gene and hypertension. Circulation. 2001 Jul 10; 104(2):187-190. [PubMed: 11447084]

38. Shioji K, Kokubo Y, Mannami T, et al. Association between hypertension and the alpha-adducin, beta1-adrenoreceptor, and G-protein beta3 subunit genes in the Japanese population; the Suita study. Hype tens Res. 2004 Jan; 27(1):31-37.

39. Johnson JA, Zineh I, Puckett BJ, McGorray SP, Yarandi HN, Pauly DF. Beta 1-adrenergic receptor polymorphisms and antihypertensive response to metoprolol. Clin Pharmacol Ther. 2003 Jul; 74(1):44-52. [PubMed: 12844134]

40. Karlsson J, Lind L, Hallberg P, et al. Beta1-adrenergic receptor gene polymorphisms and response to beta1-adrenergic receptor blockade in patients with essential hypertension. Clin Cardiol. 2004 Jun; 27(6):347-350. [PubMed: 15237695] 
Table 1

\begin{tabular}{|l|l|l|l|l|l|l|}
\hline $\begin{array}{l}\text { Adrenergic } \\
\text { receptor }\end{array}$ & $\begin{array}{l}\text { Functional } \\
\text { SNP }\end{array}$ & $\begin{array}{l}\text { Major/Minor } \\
\text { alleles }\end{array}$ & $\begin{array}{l}\text { Amino } \\
\text { acids }\end{array}$ & Proxy SNP & $\begin{array}{l}\text { r2 linkage } \\
\text { with } \\
\text { functional } \\
\text { SNP }\end{array}$ & $\begin{array}{l}\text { Major/Minor } \\
\text { alleles }\end{array}$ \\
\hline$\beta 1-\mathrm{AR}$ & $\mathrm{rs} 1801253$ & $\mathrm{C} / \mathrm{G}$ & $\mathrm{Arg} / \mathrm{Gly}$ & $\mathrm{rs} 7072938$ & 0.91 & $\mathrm{C} / \mathrm{T}$ \\
$\beta 2-\mathrm{AR}$ & $\mathrm{rs} 1042713$ & $\mathrm{G} / \mathrm{A}$ & $\mathrm{Gly} / \mathrm{Arg}$ & $\mathrm{rs} 17778257$ & 0.94 & $\mathrm{~A} / \mathrm{T}$ \\
$\beta 2-\mathrm{AR}$ & $\mathrm{rs} 1042714$ & $\mathrm{C} / \mathrm{G}$ & $\mathrm{Gln} / \mathrm{Glu}$ & $\mathrm{rs} 2400707$ & 0.96 & $\mathrm{G} / \mathrm{A}$ \\
\hline
\end{tabular}


Table 2

Participant characteristics

\begin{tabular}{|c|c|}
\hline Characteristic & Value \\
\hline \# of Participants & 497 (802 studies) \\
\hline \multicolumn{2}{|l|}{ Gender, $\mathrm{n}(\%)$} \\
\hline Male & $470(59)$ \\
\hline Female & $332(41)$ \\
\hline Age (yrs), mean (sd) [range] & $51(8)[30-74]$ \\
\hline Body Mass Index $\left(\mathrm{kg} / \mathrm{m}^{2}\right)$, mean (sd) [range] & $30(5)[17-52]$ \\
\hline Blood Pressure Medication Use, n (\%) & NA \\
\hline $\begin{array}{l}\text { Measured Hypertension using Wake Blood } \\
\text { pressure, } \mathrm{n}(\%)\end{array}$ & $108(13)$ \\
\hline $\begin{array}{l}\text { Mean Wake Systolic Blood Pressure, mmHg, } \\
\text { (sd) }\end{array}$ & $126(12)$ \\
\hline $\begin{array}{l}\text { Mean Sleep Systolic Blood Pressure, mmHg, } \\
\text { (sd) }\end{array}$ & $107(12)$ \\
\hline $\begin{array}{l}\text { Mean Wake Diastolic Blood Pressure, mmHg, } \\
\text { (sd) }\end{array}$ & $77(7)$ \\
\hline $\begin{array}{l}\text { Mean Sleep Diastolic Blood Pressure, mmHg, } \\
\text { (sd) }\end{array}$ & $62(7)$ \\
\hline $\begin{array}{l}\text { Mean Sleep/Wake Ratio for Systolic Blood } \\
\text { Pressure (sd) }\end{array}$ & $0.85(0.06)$ \\
\hline $\begin{array}{l}\text { Mean Sleep/Wake Ratio for Diastolic Blood } \\
\text { Pressure (sd) }\end{array}$ & $0.81(0.07)$ \\
\hline $\begin{array}{l}\text { Non-Dipping Systolic Blood Pressure } \\
\text { (Wake/Sleep Ratio >0.90), n }(\%)\end{array}$ & $143(18)$ \\
\hline $\begin{array}{l}\text { Non-Dipping Diastolic Blood Pressure } \\
(\text { Wake/Sleep Ratio >0.90), n }(\%)\end{array}$ & $87(11)$ \\
\hline rs2400707 & \\
\hline AA & $166(21)$ \\
\hline AG & $342(43)$ \\
\hline GG & $294(37)$ \\
\hline rs17778257 & \\
\hline TT & $155(19)$ \\
\hline $\mathrm{AT}$ & $353(44)$ \\
\hline AA & $292(37)$ \\
\hline rs7072938 & \\
\hline $\mathrm{CC}$ & $30(4)$ \\
\hline $\mathrm{CT}$ & $333(47)$ \\
\hline $\mathrm{TT}$ & $350(49)$ \\
\hline
\end{tabular}


Table 3

\begin{tabular}{|c|c|c|c|c|}
\hline Characteristic & rs2400707 AA & rs2400707 AG & rs2400707 GG & p-value \\
\hline $\begin{array}{l}\text { Male Gender, M n } \\
(\%)\end{array}$ & $97(58)$ & $201(59)$ & $172(59)$ & 0.89 \\
\hline Age & $53(8)$ & $51(8)$ & $51(9)$ & 0.29 \\
\hline BMI, kg/m² (SD) & $29(6)$ & $29(6)$ & $30(5)$ & 0.93 \\
\hline $\begin{array}{l}\text { Mean wake SBP, } \\
\mathrm{mmHg}(\mathrm{SD})\end{array}$ & $126(11)$ & $127(13)$ & $126(11)$ & 0.5 \\
\hline $\begin{array}{l}\text { Mean wake DBP, } \\
\mathrm{mmHg} \text { (SD) }\end{array}$ & 77 (7) & $77(8)$ & $76(7)$ & 0.68 \\
\hline $\begin{array}{l}\text { Mean sleep SBP, } \\
\text { mmHg (SD) }\end{array}$ & 109 (12) & $107(12)$ & $106(11)$ & 0.21 \\
\hline $\begin{array}{l}\text { Mean sleep DBP, } \\
\text { mmHg (SD) }\end{array}$ & $63(8)$ & $62(8)$ & $61(7)$ & 0.15 \\
\hline $\begin{array}{l}\text { Mean sleep/wake } \\
\text { systolic dipping } \\
\text { ratio (SD) }\end{array}$ & $0.86(0.06)$ & $0.85(0.06)$ & $0.84(0.05)$ & 0.04 \\
\hline $\begin{array}{l}\text { Mean sleep/wake } \\
\text { diastolic dipping } \\
\text { ratio (SD) }\end{array}$ & $0.83(0.08)$ & $0.81(0.07)$ & $0.80(0.07)$ & 0.050 \\
\hline $\begin{array}{l}\text { Non-dipping } \\
\text { systolic BP, n (\%) }\end{array}$ & $40(24)$ & $59(17)$ & $44(15)$ & 0.19 \\
\hline $\begin{array}{l}\text { Non-dipping } \\
\text { diastolic BP, n (\%) }\end{array}$ & $27(16)$ & $37(11)$ & $23(8)$ & 0.08 \\
\hline
\end{tabular}

Table 3 b- Participant characteristics by $\beta 2-\mathrm{AR}$ rs17778257 genotype ( $\mathrm{N}=800$ studies)

\begin{tabular}{l|c|c|c|c}
\hline Characteristic & rs17778257 TT & rs17778257 AT & rs17778257 AA & p-value \\
\hline $\begin{array}{l}\text { Male Gender, M } \\
\text { n (\%) }\end{array}$ & $95(61 \%)$ & $208(59 \%)$ & $167(57 \%)$ & 0.84 \\
Age & $51(9)$ & $50(8)$ & $52(8)$ & 0.33 \\
BMI, kg/m² (SD) & $29.1(5)$ & $29.7(6)$ & $29.6(6)$ & 0.3 \\
$\begin{array}{l}\text { Mean wake SBP, } \\
\text { mmHg (SD) }\end{array}$ & $125(11)$ & $126(13)$ & $127(11)$ & 0.59 \\
$\begin{array}{l}\text { Mean wake DBP, } \\
\text { mmHg (SD) }\end{array}$ & $76(7)$ & $77(8)$ & $77(7)$ & 0.43 \\
$\begin{array}{l}\text { Mean sleep SBP, } \\
\text { mmHg (SD) }\end{array}$ & $106(12)$ & $107(12)$ & $108(12)$ & 0.64 \\
$\begin{array}{l}\text { Mean sleep DBP, } \\
\text { mmHg (SD) }\end{array}$ & $62(7)$ & $61.9(7)$ & $63(8)$ & 0.31 \\
$\begin{array}{l}\text { Mean sleep/wake } \\
\text { systolic dipping } \\
\text { ratio (SD) }\end{array}$ & $0.85(0.06)$ & $0.85(0.05)$ & $0.85(0.06)$ & 0.85 \\
$\begin{array}{l}\text { Mean sleep/wake } \\
\text { diastolic dipping } \\
\text { ratio (SD) }\end{array}$ & $0.81(0.07)$ & $0.81(0.07)$ & $0.82(0.08)$ & 0.47 \\
$\begin{array}{l}\text { Non-dipping } \\
\text { systolic BP, } \\
\text { (\%) }\end{array}$ & $26(17 \%)$ & $57(16 \%)$ & $60(21 \%)$ & 0.53 \\
\end{tabular}




\begin{tabular}{|c|c|c|c|c|}
\hline Characteristic & rs17778257 TT & rs17778257 AT & rs17778257 AA & p-value \\
\hline $\begin{array}{l}\text { Non-dipping } \\
\text { diastolic BP, n } \\
(\%)\end{array}$ & $17(11 \%)$ & $31(9 \%)$ & $39(13 \%)$ & 0.33 \\
\hline
\end{tabular}

\begin{tabular}{|c|c|c|c|c|}
\hline Characteristic & rs7072938 CC & rs7072938 CT & rs7072938 TT & p-value \\
\hline Gender, M n (\%) & $11(37)$ & $187(56)$ & $220(63)$ & 0.20 \\
\hline Age & $50(7)$ & $51(8)$ & $52(9)$ & 0.91 \\
\hline BMI, kg/m² (SD) & $29(6)$ & $30(6)$ & $29(5)$ & 0.20 \\
\hline $\begin{array}{l}\text { Mean wake SBP, } \\
\text { mmHg (SD) }\end{array}$ & $120(11)$ & $126(12)$ & $127(12)$ & 0.17 \\
\hline $\begin{array}{l}\text { Mean wake DBP, } \\
\mathrm{mmHg} \text { (SD) }\end{array}$ & $73(6)$ & $77(8)$ & 77 (7) & 0.09 \\
\hline $\begin{array}{l}\text { Mean sleep SBP, } \\
\mathrm{mmHg} \text { (SD) }\end{array}$ & $103(10)$ & $107(12)$ & $107(12)$ & 0.38 \\
\hline $\begin{array}{l}\text { Mean sleep DBP, } \\
\mathrm{mmHg} \text { (SD) }\end{array}$ & $59(6)$ & $62(8)$ & $62(7)$ & 0.20 \\
\hline $\begin{array}{l}\text { Mean sleep/wake } \\
\text { systolic dipping } \\
\text { ratio (SD) }\end{array}$ & $0.86(0.05)$ & $0.85(0.06)$ & $0.85(0.06)$ & 0.77 \\
\hline $\begin{array}{l}\text { Mean sleep/wake } \\
\text { diastolic dipping } \\
\text { ratio (SD) }\end{array}$ & $0.82(0.06)$ & $0.81(0.08)$ & $0.81(0.07)$ & 0.99 \\
\hline $\begin{array}{l}\text { Non-dipping } \\
\text { systolic BP, n } \\
(\%)\end{array}$ & $7(23)$ & $58(17)$ & $59(17)$ & 0.76 \\
\hline $\begin{array}{l}\text { Non-dipping } \\
\text { diastolic BP, } \mathrm{n} \\
(\%)\end{array}$ & $3(10)$ & $40(12)$ & $32(9)$ & 0.61 \\
\hline
\end{tabular}


Table 4

Association of $\beta 1-\mathrm{AR}$ and $\beta 2-\mathrm{AR}$ variants with non-dipping status

\begin{tabular}{|c|c|c|}
\hline & $\begin{array}{c}\text { Systolic Non-Dipping } \\
\text { OR (95\% Confidence Interval) }\end{array}$ & $\begin{array}{l}\text { Diastolic Non Dipping } \\
\text { OR (95\% Confidence Interval) }\end{array}$ \\
\hline \multicolumn{3}{|l|}{ rs2400707 } \\
\hline GG & REF & REF \\
\hline $\mathrm{AG}$ & $1.19(0.77,1.84)$ & $1.52(0.87,2.66)$ \\
\hline \multirow[t]{2}{*}{ AA } & $1.68(0.96,2.94)$ & $2.14(1.10,4.16)$ \\
\hline & p-trend $=0.077$ & $\mathrm{p}$-trend $=0.023$ \\
\hline \multicolumn{3}{|l|}{ rs17778257 } \\
\hline TT & REF & REF \\
\hline AT & $1.1(0.6,1.8)$ & $0.9(0.4,1.6)$ \\
\hline \multirow[t]{2}{*}{ AA } & $1.2(0.7,2.1)$ & $1.2(0.6,2.2)$ \\
\hline & $\mathrm{p}$-trend $=0.44$ & $\mathrm{p}$-trend $=0.51$ \\
\hline \multicolumn{3}{|l|}{ rs7076938 } \\
\hline $\mathrm{TT}$ & REF & REF \\
\hline $\mathrm{CT}$ & $1.0(0.7,1.6)$ & $1.3(0.8,2.2)$ \\
\hline \multirow[t]{2}{*}{$\mathrm{CC}$} & $1.4(0.5,3.9)$ & $1.0(0.3,3.0)$ \\
\hline & $\mathrm{p}$-trend $=0.59$ & $\mathrm{p}$-trend $=0.43$ \\
\hline \multicolumn{3}{|l|}{ Haplotype Analyses } \\
\hline \multicolumn{3}{|l|}{$\mathrm{T} / \mathrm{G}^{*}$} \\
\hline 0 & REF & REF \\
\hline 1 & $0.8(0.5,1.3)$ & $0.7(0.4,1.2)$ \\
\hline \multirow[t]{2}{*}{2} & $0.8(0.5,1.3)$ & $0.8(0.4,1.5)$ \\
\hline & $\mathrm{p}$-trend $=0.35$ & $\mathrm{p}$-trend $=0.39$ \\
\hline \multicolumn{3}{|l|}{$\underline{\mathrm{A} / \mathrm{G}}$} \\
\hline$\underline{0}$ & REF & REF \\
\hline 1 & $0.9(0.6,1.4)$ & $0.7(0.4,1.1)$ \\
\hline \multirow[t]{2}{*}{2} & $0.3(0.1,1.5)$ & $0.2(0.0,2.0)$ \\
\hline & $\mathrm{p}$-trend $=0.2$ & $\mathrm{p}$-trend $=0.04$ \\
\hline \multicolumn{3}{|l|}{$\underline{\mathrm{A} / \mathrm{A}}$} \\
\hline$\underline{0}$ & REF & REF \\
\hline 1 & $1.2(0.8,1.9)$ & $1.6(0.9,2.8)$ \\
\hline \multirow[t]{2}{*}{2} & $1.6(0.9,2.8)$ & $2.0(1.0,3.8)$ \\
\hline & $\mathrm{p}$-trend $=0.11$ & $\mathrm{p}$-trend $=0.04$ \\
\hline
\end{tabular}

* T/G tags for Arg16Gln27; A/G tags for Gly16Gln27, and A/A tags for Gly16Glu27 
Table 5

Association of $\beta 2-$ AR and $\beta 1-A R$ SNPS and $\beta 2-A R$ haplotype with Systolic and Diastolic Dipping Ratio ${ }^{+}$

\begin{tabular}{|c|c|c|}
\hline & Mean Systolic Dip Ratio* & Mean Diastolic Dip Ratio \\
\hline \multicolumn{3}{|l|}{ rs2400707 } \\
\hline GG & $0.846(0.004)$ & $0.807(0.01)$ \\
\hline $\mathrm{AG}$ & $0.854(0.004)$ & $0.815(0.01)$ \\
\hline \multirow[t]{2}{*}{$\mathrm{AA}$} & $0.861(0.005)$ & $0.824(0.01)$ \\
\hline & p-trend $=0.015$ & $\mathrm{p}$-trend $=0.026$ \\
\hline \multicolumn{3}{|l|}{ rs17778257 } \\
\hline TT & $0.8511(0.01)$ & $0.811(0.01)$ \\
\hline AT & $0.8531(0.004)$ & $0.8134(0.01)$ \\
\hline \multirow[t]{2}{*}{ AA } & $0.8534(0.004)$ & $0.8180(0.01)$ \\
\hline & $\mathrm{p}$-trend $=0.74$ & $\mathrm{p}$-trend $=0.36$ \\
\hline \multicolumn{3}{|l|}{ rs7076938 } \\
\hline TT & $0.851(0.004)$ & $0.814(0.01)$ \\
\hline $\mathrm{CT}$ & $0.852(0.004)$ & $0.815(0.01)$ \\
\hline \multirow[t]{2}{*}{$\mathrm{CC}$} & $0.856(0.01)$ & $0.815(0.02)$ \\
\hline & $\mathrm{p}$-trend $=0.69$ & $\mathrm{p}$-trend $=0.83$ \\
\hline \multicolumn{3}{|l|}{ Haplotype Analyses } \\
\hline \multicolumn{3}{|l|}{$\mathrm{T} / \mathrm{G}$} \\
\hline$\underline{0}$ & $0.854(0.004)$ & $0.819(0.01)$ \\
\hline 1 & $0.852(0.004)$ & $0.813(0.01)$ \\
\hline \multirow[t]{2}{*}{$\underline{2}$} & $0.851(0.01)$ & $0.811(0.01)$ \\
\hline & $\mathrm{p}$-trend $=0.61$ & $\mathrm{p}$-trend $=0.29$ \\
\hline \multicolumn{3}{|l|}{$\mathrm{A} / \mathrm{G}$} \\
\hline 0 & $0.856(0.003)$ & $0.817(0.004)$ \\
\hline 1 & $0.846(0.01)$ & $0.812(0.01)$ \\
\hline \multirow[t]{2}{*}{$\underline{2}$} & $0.834(0.012)$ & $0.792(0.015)$ \\
\hline & p-trend $=0.01$ & $\mathrm{p}$-trend $=0.14$ \\
\hline \multicolumn{3}{|l|}{$\mathrm{A} / \mathrm{A}$} \\
\hline$\underline{0}$ & $0.847(0.004)$ & $0.807(0.01)$ \\
\hline 1 & $0.855(0.004)$ & $0.816(0.01)$ \\
\hline \multirow[t]{2}{*}{2} & $0.860(0.01)$ & $0.823(0.01)$ \\
\hline & p-trend $=0.03$ & $\mathrm{p}$-trend $=0.04$ \\
\hline
\end{tabular}

* Least Square Means adjusted for age, sex, body mass index, heritage T/G tags for Arg16Gln27; A/G tags for Gly16Gln27, and A/A tags for Gly16Glu27 